\title{
Giuseppe Panella, Forme del romanzo tra umorismo e irradiazione del sublime. La prospettiva di Honoré de Balzac
}

\section{Marco Stupazzoni}

\section{(2) OpenEdition \\ Journals}

\section{Edizione digitale}

URL: http://journals.openedition.org/studifrancesi/9598

DOI: 10.4000/studifrancesi.9598

ISSN: 2421-5856

\section{Editore}

Rosenberg \& Sellier

\section{Edizione cartacea}

Data di pubblicazione: 1 décembre 2007

Paginazione: 679-680

ISSN: 0039-2944

\section{Notizia bibliografica digitale}

Marco Stupazzoni, «Giuseppe Panella, Forme del romanzo tra umorismo e irradiazione del sublime. La prospettiva di Honoré de Balzac», Studi Francesi [Online], 153 (LI | III) | 2007, online dal 30 novembre 2015, consultato il 13 janvier 2021. URL: http://journals.openedition.org/studifrancesi/9598 ; DOI: https://doi.org/10.4000/studifrancesi.9598

Questo documento è stato generato automaticamente il 13 janvier 2021.

\section{cc) $(9)$}

Studi Francesi è distribuita con Licenza Creative Commons Attribuzione - Non commerciale - Non opere derivate 4.0 Internazionale. 


\title{
Giuseppe Panella, Forme del romanzo tra umorismo e irradiazione del sublime. La prospettiva di Honoré de Balzac
}

\author{
Marco Stupazzoni
}

\section{NOTIZIA}

GIUSEPPE PANELLA, Forme del romanzo tra umorismo e irradiazione del sublime. La prospettiva di Honoré de Balzac, in Il Sublime e la prosa. Nove proposte di analisi letteraria, Firenze, Editrice Clinamen, 2005, pp. 107-121.

In questo capitolo, Giuseppe Panella riflette sulle origini del romanzo moderno riferendosi inizialmente alla relazione tra humour e scrittura finzionale stabilito da Milan Kundera nel suo L'Arte del romanzo, per quel che riguarda più particolarmente il tentativo di cogliere e di rappresentare «la soggettività degli individui nel loro rapporto con le certezze e con la verità» (p. 109). Di rilevanza non certo secondaria è inoltre il legame tra estetica e romanzo sotto il profilo filosofico in relazione alla interpretazione del reale: da questo punto di vista, l'attribuzione di un valore non soltanto storico-letterario, ma, appunto, filosofico del suo progetto romanzesco da parte di Balzac nell'Avant-propos del 1842 si concretizza, a giudizio di Panella, in un orizzonte di scrittura inteso come quel «momento capace di verificare la novità oggettiva» di tale ambizioso progetto. La pluridiscorsività presente nell'opera balzachiana «è messa in evidenza proprio dalla volontà del suo autore di rivelarne la natura sociale e morale». In questo senso, il riferimento ad Adieu, un testo, osserva l'autore, scritto «all'insegna del Sublime» (p. 119), consente di verificare «nell'architettura della scrittura di Balzac e nella sua pratica linguistica un tipico 
esempio di stilizzazione che fuoriesce dalla pura imitazione stilistica e si definisce come progetto di unificazione della pluridiscorsività dell'approccio romanzesco» (p. 118). 